\title{
Statyba
}

\section{PROBLEMS OF APPLICATION AND DESIGN OF SHELL FOUNDATIONS}

\section{J. Amšiejus , R. Gruodis \& P. Janulevičius}

To cite this article: J. Amšiejus, R. Gruodis \& P. Janulevičius (1997) PROBLEMS OF APPLICATION AND DESIGN OF SHELL FOUNDATIONS, Statyba, 3:11, 76-81, DOI: 10.1080/13921525.1997.10531357

To link to this article: https://doi.org/10.1080/13921525.1997.10531357

曲 Published online: 26 Jul 2012.

Submit your article to this journal

III Article views: 291 


\title{
PROBLEMS OF APPLICATION AND DESIGN OF SHELL FOUNDATIONS
}

\author{
J. Amšicjus, R. Gruodis, P. Janulevičius
}

\section{Introduction}

For a number of years bored short piles characterized by simple and efficient technology have been successfully applied in Lithuania. Their basic disadvantage is that insufficient advantage is taken of the structural foundation strength what leads to an undesirably large amount of concrete to be used for the foundation installation. Even in comparison with the conventional independent foundations for columns, bored short piles of $1 \mathrm{~m}^{3}$ possess a lower bearing capacity. Besides, unless the collapse of borehole walls is prevented, the quality of a structure itself is lowered during concreting. This has encouraged the seeking for new and more efficient solutions.

Among the conventional foundation types the so-called shell foundation, mostly of a ring crosssection and of a cylindrical or conical shape, permit to take advantage of the strength of a structural foundation most efficiently [1]. However, as a rule, this advantage is lowered by irrational techniques of the manufacture and installation of such foundations. In seeking for something like a compromise between these entirely different types of structural foundations, reinforced concrete non-pressure tubes have been selected which have been widely used in draining systems and the demand for which has recently decreased considerably. The cylindrical shape of these tubes pcrmits to apply the essential technological advantage of bored short piles to a tubular structure of this type what enables to reach the design altitude of the foundation base by drilling instead of the conventional digging process. In this case the reinforced concrete tubes would be set into the boreholes of a slightly larger cross-section. Naturally, the space between the foundation and the borehole wall is to be filled with the same compacted soil. In comparison with bored short piles, the amount of concrete used is rcduced to three and more times, while the manufacture and installation costs are decreased twice [2]. Shell foundations of this type, which probably should be termed tubular foundations, would be made even more efficient, if they were sunk to the design position by a driving or vibration process. The term well foundations could not be applied in this case, since it refers to deep foundations of a particularly large cross-section.

\section{Construction of shell foundations and analysis peculiarities}

Reinforced concrete non-pressure tubes are manufactured in different sizes by industrialized production methods using centrifuges for compacting the concrete. Tubes with outside cross-sections of 720 and $960 \mathrm{~mm}$ and without or with couplings of 890 and $1170 \mathrm{~mm}$ correspondingly would be most suitable for structural foundations. Such foundations could replace bored short piles with the cross-sections of $600,800,1000$ and $1200 \mathrm{~mm}$. These tubes are manufactured up to $5.00 \mathrm{~m}$ in length but the length of $3.20 \mathrm{~m}$ is more acceptable in handling operations. Drilling to a larger depth would reduce the rate of the construction work, since during each lowering and raising operation of the drill additional enlarging or shortening of the latter would be needed. Moreover, a structure of the above-indicated or smaller length can be sunk into the borehole by using the same drilling aggregate, thus improving the construction work techniques considerably.

To achieve an efficient structural solution for shell foundations the problem of supporting the superstructures both under bearing walls and under columns is to be solved. The simplest solution is to fill the foundation inside with concrete. However, this method is not recommended as being particularly irrational and non-economical. Reference to the literature testified that a successful solution can be 
reached by filling the foundation inside with a chemically strengthened soil [3]. A cushion of concrete with a mesh reinforcement provided in the upper section of a foundation enables to support a bearing wall through the foundation beams, while the space left for fixing the columns makes it possible to apply such a foundation for skeleton structures. If a chemically strengthened soil is unavailable, the authors suggest to utilize ordinary thoroughly compacted sand for this purpose. A patent review shows that this method has not been applied in construction practice.

Although at first sight the above methods of filling the foundation inside seem to be similar, there exists a principal difference between them. While a chemically strengthened soil practically cannot be deformed under a load, slight vertical deformations are likely to occur with the concrete filling. The horizontal soil deformations being restricted in this case by the structural foundation itself, significant horizontal stresses are transferred to the inner surface of the foundation. This should be evaluated by a separate structural analysis. Further this procedure will be considered in greater detail.

As has been noted, the vertical force is transmitted from the superstructures to the foundation section filled with soil through a reinforced concrete cushion. The touching point between the latter and the inner surface of the tube can be regarded as a kind of a cylindrically-shaped joint the strength of which determines which portion of the load will be transferred to the underlying compacted soil. In case the joint is of an adequate area and strength, it may take the entire vertical force thus eliminating the action of any stresses in the soil below the cushion. While the height of the above joint for wall foundations is equal only to the reinforced concrete cushion height, with column foundations, the height of a column fixing adds to that of the joint (Fig 1). In that case the joint, strength may exceed the vertical force acting within the column, the underlying soil being needed rather as an additional measure. On the other hand, in the case of an inadequate height and strength of the joint, a slight soil compression duc to the cushion pressure will occur, thus causing the development of stresses acting towards the inner surface of the structure. In such a case the strength of the lateral reinforcement of a tubular foundation under the action of horizontal soil stresses is to be verified. A vertical cushion displacement would be insignificant within the gross foundation settlement.

As for the design of these unconventional foundations, some aspects of the analysis of the ground as well as of the structure itself are to be considered. The ground analysis is unlikely to cause any problems, since the size and shape of these foundations are practically the same as those for bored short piles, except that, in contrast with the latter foundation type, tubular foundations do not require any estimate of the friction along the foundation side, i.e. when selecting dimensions for a tubular foundation the vertical load should be

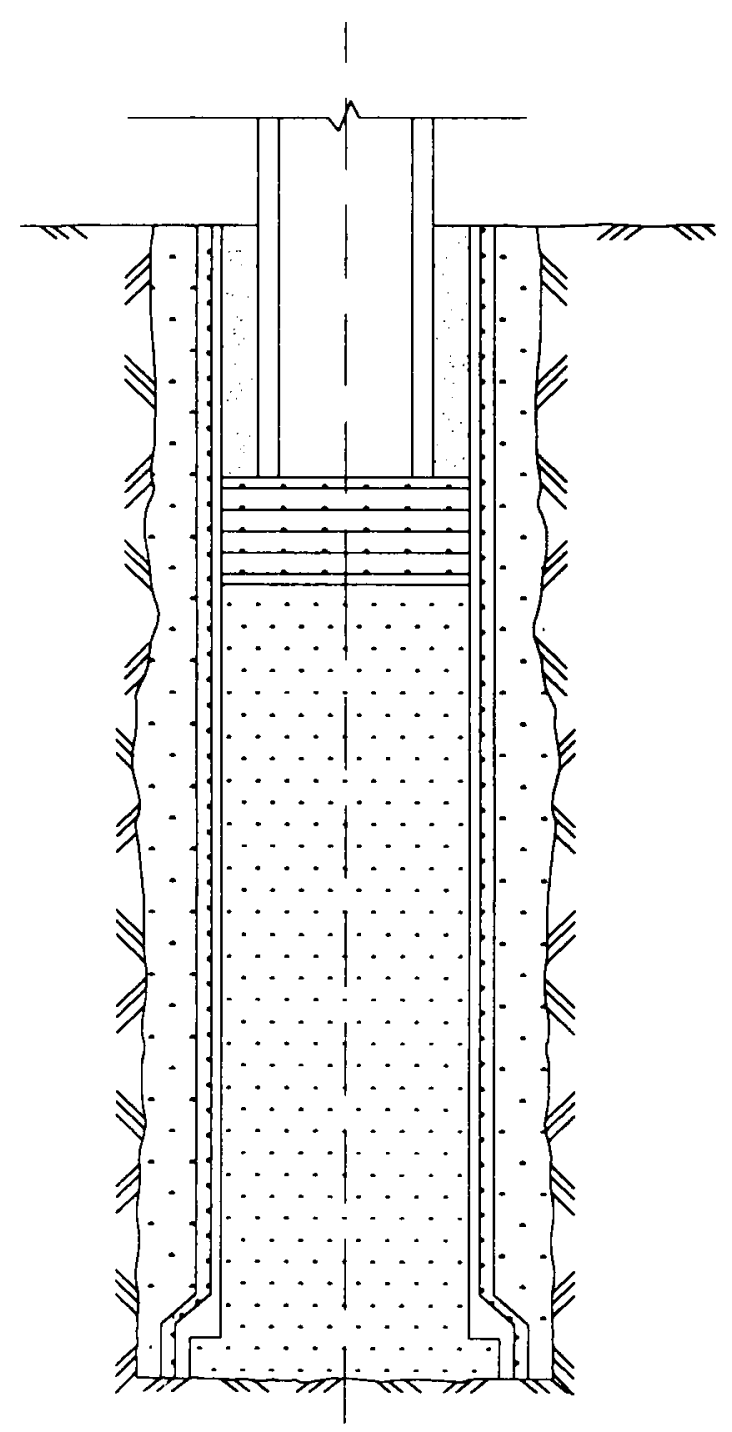

Fig 1. General view of tubular foundation 
assumed to be transferred to the ground only through the foundation base. In calculating the action of the horizontal force and that of the bending moment, the natural properties of the compacted soil fill surrounding the foundation should not be changed as well. For a structural foundation strength analysis, the determination of the very load moment is a far more essential problem, since with a high degree of taking the advantage of the strength of a tubular foundation, inaccuracies in determining the stresses may have an unfavourable influence on the crosssection dimensioning. Therefore, in order to consider this problem, an analysis of the results obtained in calculating the action of the horizontal force and that of the bending moment for a tubular foundation ground has been carried out.

\section{Analysis of calculation results for horizontal force and bending moment action}

All the foundation types, including deep foundations, are, as a rule, analysed for the action of the horizontal force and that of the bending moment without taking into account the rigidity of the connection of foundations to superstructures. But as the experience of examining superstructure connections show, the rigidity of joints between columns and collar beams or of those between in-situ concrete walls and floors is greatly dependant on the strength of the compressive prism formed in their kern. An analysis of the research works shows that this strength results from a number of factors: the intensity of axial and transverse forces, the joint width, the crossreinforcement and its anchorage, the latter factor being of an exceptional importance $[4,5,6,7]$. Quite a variety of ways have been proposed to restrict deformations of compressive concrete at cost of increased reinforcement. A denser reinforcement arrangement is mostly obtained with the help of loops and spiral reinforcement. Besides, for increasing the amount of the cross-reinforcement in one connection element, the utilization of the longitudinal reinforcement of other elements is recommended.

On the other hand, a correct calculation of stresses in a connection is also quite an important problem in this respect. That becomes especially evident when evaluating an interaction between a structure and its ground. This problem is known to be not so simple and easily solved. Therefore, an engincering solution of this problem is proposed in this work, taking into account the rigidity of connections between foundations and superstructures.

A foundation is typically considered to be loosely connected to the superstructure, the foundation torsion and displacements being unrestricted. However, that should not apply to the design of foundations for columns, since joints for fixing columns to a structural foundation are rigid. As has been noted, that is of great interest in an analysis of the so-called hollow shell foundations providing for a satisfactorily high degree of taking advantage of structural strength.

A tubular foundation the ring cross-section of which has an outside and internal diameters correspondingly of 0.72 and $0.60 \mathrm{~m}$ has been selected for this analysis. The foundation is $3.20 \mathrm{~m}$ high, its top being at the soil surface level. The B25 concrete has the modulus of elasticity $E=3 \cdot 10^{7} \mathrm{kPa}$. Stresses caused by external loads acting in this type of foundations are assumed to be of the highest degree of risk in the case when the greatest magnitude of the bending moment prevails, i.e. $N_{1}=822 \mathrm{kN}, M_{1 \max }=94$ $\mathrm{kNm}, Q_{1}=65 \mathrm{kN}$.

The ground is made up of fine and dense sand. The analysis has been performed on the basis of the technique recommended for pile foundations estimating both possible cases of connection [8]. It should be noted that this rather advanced technique does not exist in the design standards of the Eurocode system. In the first case a column is connected to the foundation loosely, i.e. the displacements and torsion of the upper section of the foundation are permitted. In the second case the connection is rigid and the torsion of the foundation top is restricted, its displacements being permitted. A complete calculation procedure is shown [9].

The calculation results have shown that in the case of a rigid connection the displacement and torsion of the upper section of the foundation are reduced twice, the maximum bending moment decreasing even by four times. This is also seen in the bending moments diagram in which the results of this analysis are summed up (Fig 2). As it is seen in the 


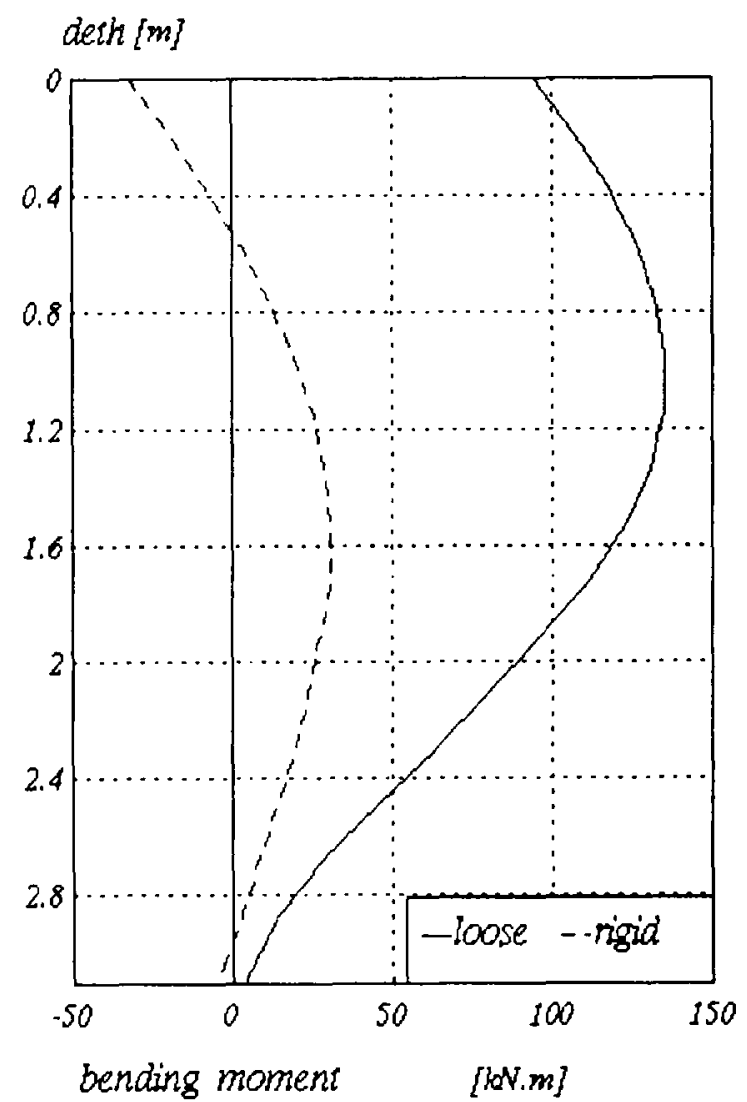

Fig 2. Diagram of bending moment

diagram, depending on the adopted computational scheme the results may vary considerably. This is due to the fact that both versions considered for a connection between a column and the foundation conform to the boundary conditions of the solution of this problem. In fact, this process is much more complex, and it is in an intermediate position among those already considered. With a rigid connection between a column and the foundation, the torsion of the upper section of the latter becomes restricted, its horizontal displacement being permitted. For this reason a fixing moment is developed which resists the action above. The torsion and horizontal displacement of the foundation top, the normal stresses along the lateral surface of the foundation as well as the bending moments due to shear force are correspondingly reduccd. On the other hand, these changes cause an opposite reaction too, i.e. with a decrease in the horizontal foundation displacement the fixing moment itself is also reduced and that in turn results in an increase of the foundation load moment. That is to say, a certain equilibrium is reached at which the values of the foundation horizontal displacement, torsion and stress distribution are in an intermediate position among those obtaincd by using the computational schemes mentioned above.

For example, for the bending moment acting in the structural foundation through its full height, in the first case, with a loose connection between a column and the foundation, the maximum value of the bending moment of $94 \mathrm{kNm}$, in contrast to that of the load moment of $94 \mathrm{kNm}$, is higher by 42 per cent. In the second case, with a rigid connection, when $M_{\max }=30 \mathrm{kNm}$, this difference already makes 68 per cent only in the opposite sense. As has been mentioned, the actual maximum bending moment values should be in an intermediate position among those calculated herein. The arithmetical mean of these values is equal to $82 \mathrm{kNm}$ and by 13 per cent lower in contrast to the load moment.

It is impossible so far to estimate precisely the magnitude of the bending moment acting in the structural foundation in this specific case. It will be possible to do this only when stresses in a structural foundation are calculated evaluating an interaction between the ground and structure. However, it is clear already now that, owing to a rigid column fixing, the maximum bending moment acting in a structural foundation is considerably reduced and in any case should not exceed the load moment in the upper section of a foundation. Therefore, when designing deep foundations for columns, a calculation of the maximum bending moment in a structural foundation is even not needed, an adoption of the foundation load moment instead of it being quite a reasonable solution. As for the results of this analysis, it is quite not the same whether, in verifying the strength of a ring cross-section, the design value of the maximum bending moment is $134 \mathrm{kNm}$ or only $94 \mathrm{kNm}$. That is an extremely important conclusion for the design of shell foundations the structural strength of which can be utilized significantly more advantageously than that of conventional foundations including bored short piles. 


\section{Conclusions and further research trends}

Finally, the analysis discussed in this paper can be summed up by listing the procedures for the design of tubular foundations. The general ground design for this type of foundations is to consist of the following procedures:

- selection of an optimum method for sinking the foundation into the ground;

- analysis of the foundation ground in accordance with the sinking method selected;

- selection of the type of soil to fill the foundation and determination of the degree of its consolidation;

- calculation of horizontal soil stresses within the foundation;

- estimation of vertical soil displacements within the foundation.

The fulfillment of the first and the last two procedures can not be accurately evaluated as yet, since these problems have not yet been thoroughly investigated. On the other hand, the design of a tubular structural foundation itself is rather problematic too. Taking into account the considerations mentioned above, the procedures for verifying the strength of a structural foundation would be the following:

- verification of the strength of a ring cross-section evaluating the influence of connection between the foundation and superstructures on the load moment;

- cushion analysis for local compression;

- verification of the column fixing strength in an oblique section;

- verification of the strength of a joint between the inside foundation surface and column fixing;

- verification of the strength of transverse reinforcement under the action of horizontal soil stresses.

As with the ground design, for the strength analysis of a structural foundation an adequate information relating to the last two design procedures is also unavailable. That is a major largely determine the future of tubular foundations. According to the present situation, a packaged research program should be the following:
- theoretical investigations utilizing finite element program packages for the analysis of the ground and foundation stress and strain state;

- experimental investigations for comparison of the results obtained;

- observation of actual settlements in buildings with this type of foundations.

A wide scale research program would greatly contribute to raising the popularity of tubular foundations and the rate of their introduction into production.

\section{References}

1. А.Н. Тетиор. Проектирование и сооружение экономичных конструкций фундаментов. Киев: БудівельHиK, 1975. 203 c.

2. J. Amšiejus, R. Gruodis. Kai kurie kevaliniu pamaty taikymo, projektavimo bei tyrimo klausimai // 4-oji tarptautine konferencuja SF 95 "Naujos medžiagos, konstrukcijos ir technologijos", T.2. V., 1995, p. 69-72.

3. Pat. EP0536486, E02D - 27/30. Fondation having cylindrical shell and construction method therefor / Kunito Mitsuhiro (Japonija). - Nr. 92112469.9; Paraiška 21.07.92; Publ. 14.04.93, Prioritet. 08.10.91 JP $287337 / 91$.

4. C.K. Dudley, R. Park. Flexsural Members with Confined Concrete // Journal of Structural Division, Proceedings of ASCE. - 1971. Vol. 97, N 7, p. 19691990.

5. D.F. Meinheit, J.O. Jirsa. Shear Strength of R/C BeamColumn Connections // Journal of Structural Division, Proceedings of ASCE. 1981. Vol. 107, N 11, p. $2227-$ 2244.

6. N.G. Gilson, M.E. Kreger, J.O. Jirsa. Evaluation of Joint-Shear Provisions for Interior Beam-Column-Slab Connections Using High-Strength Materials // ACI Structural Journal. 1992. Vol. 89, N 1, p. 89-98.

7. S. Pantazopoulou, I. Imran. Slab-Wall Connections under Lateral Forces // ACI Structural Journal. 1992. Vol. 89, N 5, p. 515-527.

8. СНиП II-17-77. Нормы проектирования. Свайные фундаменты. 45 с.

9. J. Amšiejus, R. Gruodis. Giliuju pamatu pagrindo skaičiavimo bendram jëgu poveikiui analizè // 4-oji tarptautinè konferencuja SF 95 "Naujos medžiagos, konstrukcijos ir technologijos”, T.3. V., 1995, p. 276280.

İteikta 19970210 


\section{KEVALINIU PAMATU NAUDOJIMO IR PROJEKTAVIMO KLAUSIMAI}

\section{J. Amšiejus, R. Gruodis, P. Janulevičius}

\section{Santrauka}

Iš žinomy pamaty tipu pamato konstrukcijos stiprumas efektyviausiai naudojamas parenkant tuščiavidurius, vadinamuosius kevalinius pamatus, dažniausiai žiedinio skerspjūvio, cilindro arba kūgio formos. Tačiau ši privalumą, kaip taisyklè, menkina neracionali tokių pamatų gamybos bei irrengimo technologija.

Darbe apsistota ties melioracijoje plačiai naudotais gelžbetoniniais beslègiais vamzdžiais, kurị poreikis pastaruoju metu gerokai sumažèjęs. Ju cilindro forma leidžia šiai vamzdinei konstrukcijai taikyti pagrindini gręžininiu pamatų technologijos pranašumą, kurio deka pamato pado projektinè altitudè pasiekiama ne tradiciniu kasimu, bet gręžimu. Šiuo atveju gelžbetoniniai vamzdžiai būtų istatomi i šiek tiek didesnio skersmens gręžinius. Susidariusị tarpą tarp pamato ir gręžinio sienučių būtina užpildyti tuo pačiu, tačiau sutankintu gruntu. Autorių j̨sitikinimu, viršutinèje pamato dalyje ịrengus gelžbetoninę pagalvę, visą kitą vidinę pamato dalį pakanka užpildyti paprasčiausiu gerai sutankintu sméliu, vietoj seniau naudoto prekinio betono. Patentinè paieška parodé, kad toks būdas statybos praktikoje dar netaikytas. Lyginant su gręžininiais pamatais, šiuo metodu betono sutaupoma 3 ir daugiau kartų, o gamybos bei ịrengimo išlaidų - iki 2 kartų. Tokio tipo kevaliniai pamatai, galbūt net vadintini vamzdiniais, tapty dar efektyvesniais, jeigu iki projektinès padèties būty gramzdinami kalamuoju arba vibraciniu būdu.

Straipsnyje paliesti naujos pamaty konstrukcijos taikymo, projektavimo bei tyrimo klausimai. Parodoma, kad pamato apkrovimo momento reikšmé labai priklauso nuo pasirinktos skaičiuojamosios schemos, pagal kurią pamato sujungimas su antžeminèmis konstrukcijomis gali bũti laisvasis arba standusis. Kaip rodo skaiciavimo rezultatai, standžiojo sujungimo atveju pamato viršutinès dalies poslinkis bei posūkis sumažèja iki 2, o maksimalus lenkimo momentas - net iki 4 karty̨. Aptariami ir kiti šiu pamatų projektavimo ypatumai bei tolesnių tyrimų kryptys.

Pavelas JANULEVIČIUS. Engineer. Vilnius Gediminas Technical University (VGTU, formerly VTU, VISI), 11 Sauletekio Ave, 2040 Vilnius, Lithuania.

First degree in Civil Engineering, VTU, 1994. Master of Science, VTU, 1996. Research interests: strength test of combined reinforced concrete tubular foundation. 